\title{
Using Facebook in EFL Writing Class: Its Effectiveness from Students' Perspective
}

\section{Rahmah Fithriani, Utami Dewi, Sholihatul Hamidah Daulay, Maryati Salmiah, and Widia Fransiska}

Universitas Islam Negeri Sumatera Utara (UIN SU), Medan, Indonesia

\section{Abstract}

Social media has now much been integrated as a learning platform in various educational settings, including those in Language Teaching and Learning (LTL). Increasing number of studies has also reported the effectiveness of social media to support LTL activities. This present study aimed to investigate whether Facebook, as the most popular social media in Indonesia, would be an effective learning tool for EFL university students taking advanced writing class. This study employed a case study qualitative approach. The data were collected through questionnaire, interview, and observation of students' discussion on Facebook and then analyzed using frequency count and thematic content analysis. The findings reveal that most students find the

Corresponding Author:

Rahmah Fithriani

rahmahfithriani@uinsu.ac.id

Received: 1 July 2019

Accepted: 18 July 2019

Published: 31 July 2019

Publishing services provided by

Knowledge E

(c) Rahmah Fithriani et al. This article is distributed under the terms of the Creative Commons

Attribution License, which

permits unrestricted use and

redistribution provided that the

original author and source are credited.

Selection and Peer-review unde the responsibility of the AICLL 2019 Conference Committee.

\section{G OPEN ACCESS} use of Facebook in writing class effective in boosting their confidence in using English as communicative means, encouraging their participation in class discussion, and improving their English language proficiency, particularly the writing skill. This study suggests that Facebook can be used as a supplementary learning tool in higher education classrooms as it brings positive effect not only on students' learning habits but also competence.

Keywords: CALL, digital immigrant, digital native, Facebook, MALL, social media, SNS, TILL

\section{Introduction}

A fourth industrial revolution, also known as Industry 4.0 has emerged in the past few decades, which is characterized with more emphasis on the use of digital technology. Therefore, technology integration in every aspect of human life is inevitable nowadays, including in language teaching and learning (LTL). The use of technology in LTL itself had been introduced long before Industry 4.0 emerged through the term Computer Assisted Language Learning (CALL). CALL's origins can be traced back to the 1960s and has been constantly evolving from "traditional" drill-and-practice programs into virtual learning environment in Mobile-Assisted Language Learning (MALL). 
Mobile-Assisted Language Learning (MALL) can simply be defined as an approach to enhance language learning by making use handheld mobile devices. As a successor of CALL, MALL can be a great resource offering benefits that the predecessor could not provide such as "the potential for learning process to be personalized, spontaneous, informal and ubiquitous" (Miangah \& Nezarat, 2012, p. 309). Furthermore, MALL can also be an ideal solution to language learning barriers in terms of time and place as learners do not need to sit in a classroom or in front of computers to participate in language teaching and learning activities.

MALL as an approach to language teaching and learning has also been practiced in Indonesia. A growing body of research focusing on the use of MALL in English as a foreign language (EFL) context in Indonesia has been conducted in the last few years (e.g. Darmawati, 2018; Rionaldi, 2016; Yudhiantara \& Nasir, 2017). The findings of those studies have indicated that MALL has potential to support students' language learning process. Furthermore, since mobile devices such as smartphones, tablets, and PDA (personal digital assistant) come along with thousand applications available to offer to users, which also have great potential to be integrated in language learning.

One type of application which is now much used in LTL, particularly in EFL context is Social Networking Service (SNS), which has the main purpose to connect with other people. One method of social networking is through social media which allows its users to interact and share different types of contents, such as videos, blogs, newsletter, podcast, etc. Among social media applications with the highest number of users are Facebook, YouTube, WhatsApp, Instagram, and Twitter (Ahmad, 2019). Consequently, these applications have also much been integrated in LTL practices, including in EFL teaching and learning.

Some English language teachers, practitioners, and researchers in Indonesia have also begun using MALL and/or social media in their practices (Darmawati, 2018; Fithriani, Rafida, \& Siahaan, 2018; Yudhiantara \& Nasir, 2017). It is not surprising since Indonesia is listed as one of top ten countries with the highest number of social media users, particularly Facebook (look at Figure 1). In addition, Indonesia is also reported to have 32.7 million internet users, which points to a penetration rate of $50 \%$ of the population (Husain, 2018). This means MALL and social media, particularly Facebook have great potential to be integrated in EFL classes in Indonesia.

However, despite this potential, Indonesian EFL teachers have not much used Facebook in their teaching practices, particularly in writing class. This hesitation in using social media in Indonesian EFL writing class might be rooted from some reasons related to the condition of writing class and/or the application. Among the reasons 
related to the condition of EFL writing instruction in Indonesia are students' perception of English writing as one of the most difficult skills to master (Fithriani, 2018a) and the use of traditional approach to teaching writing that views students' writing as a product instead of a process (Fithriani, 2017). Meanwhile, the reasons related to the social media applications include its potential as both a tool and a distraction in the classroom and instructors' limitation in taking a full charge of what their students do with social media beyond their supervision (Rodliyah, 2016).

Research investigating how social media applications, particularly Facebook are used in EFL writing classes in Indonesia has not extensively been explored either. Few studies have been conducted focusing on this issue (e. g. Khusnita, 2017; Nurhidayati, 2014; Rodliyah, 2016; Susanti, 2013.). Furthermore, these studies put a great emphasis on the qualitative effect and impact of MALL and Facebook use while very few have been conducted to investigate how students perceive the effectiveness of Facebook on their learning of English writing skills. Thus, regarding this gap in the existing literature, this study was aimed to investigate whether Facebook, as the most popular social media in Indonesia, would be an effective learning tool for EFL university student taking an advanced writing class. It is hoped that the findings of this study help place the focus of EFL instruction in Indonesia not only on qualitative improvement of language skills but also on students' voices and experiences during learning process.

\section{Literature Review}

\subsection{Technology integration in language learning}

The advancement of technology development has impacted every aspects of humans' lives, including personal, social, and professional ones. For language teachers, this advancement has directly affected their teaching practices through its integration into their conventional teaching syllabus and material. This integration of technology in LTL is inevitable since today's learners have different way of learning if compared to their teachers' in the past. Prensky (2001) defined today's learners as 'digital natives' while their teachers 'digital immigrants'. He defined digital natives as the "native speakers of the digital language of computers, video games and the Internet" and digital immigrants as "those who were not born into the digital world but have, at some later point of lives, become fascinated by and adopted many or most aspects of the new technology are" (Prensky, 2001, p. 1-2). He furthermore explained that the digital natives tend to be less interested in participating in the conventional classroom since they can access the 
information faster than their teachers, the digital immigrants. Thus, to solve this problem, digital immigrant teachers should develop new skills of integrating technology when teaching the digital native students. Similar to this argument, Chapelle and Jamieson (2008) stated that teachers who fail to integrate technology in language teaching are likely to be considered behind the times.

Technology Integration in Language Learning can be understood as the use of technology to support the language learning process. Gilakjani (2017) defines technology integration as the way of using technology to perform and re-shape the activities effectively. Teachers may use technology to create tasks for their students (Keser, Uzunboylu, \& Ozdamli, 2012) and create local and global communities that will connect the fellow teachers and promote learning opportunities (Bransford, Brown, \& Cocking, 2000). TILL will also provide teachers unlimited teaching resources to let students undergo various language learning experiences such as digital reading and writing, listening to podcast, watching movies, and communicating through SNS (Larsen-Freeman \& Anderson, 2011). Research also found that the convenience that TILL brings play significant roles to motivate students in learning a new language (Ahmadi, 2018) and to enhance students' enthusiasm in language learning (Arifah, 2014). In short, TILL brings positive impacts for LTL process.

\subsection{MALL and facebook use in Indonesian EFL context}

As discussed in the previously, today's teachers as digital immigrants should understand that digital native language learners have become more autonomous in their learning process, for instance; students have mastered the lesson before the teachers explained it in the classroom (Hennessy, Ruthven, \& Brindley, 2005). Teachers should also realize that technology has changed the methods of learning, from the teacher-centered to be learner-centered. Thus, as the facilitators for students' learning, teachers should support students in gathering information and using the technology wisely for practicing their language beyond the classroom, for example; through Mobile devices.

Mobile-Assisted Language Learning (MALL) is the use of mobile devices to support the language learning process and make the learning to be more interesting and fun. MALL gives language learners opportunity to learn anywhere and at any time using mobile devices (Segav, 2014). Communicating on SNS through mobile phones could improve students' motivation, engagement and real social interaction. In their study, Parvin and Salam (2015) prove that technology provides opportunities to learn languages in a meaningful context because learners involve in social interactions and 
experience real life skills. In line with this, a research by Alsaleem (2014) also shows that social media can improve students' writing skills, speaking skills, vocabulary and diction. These studies indicate that MALL and social media are surely great tools to support the language learning process.

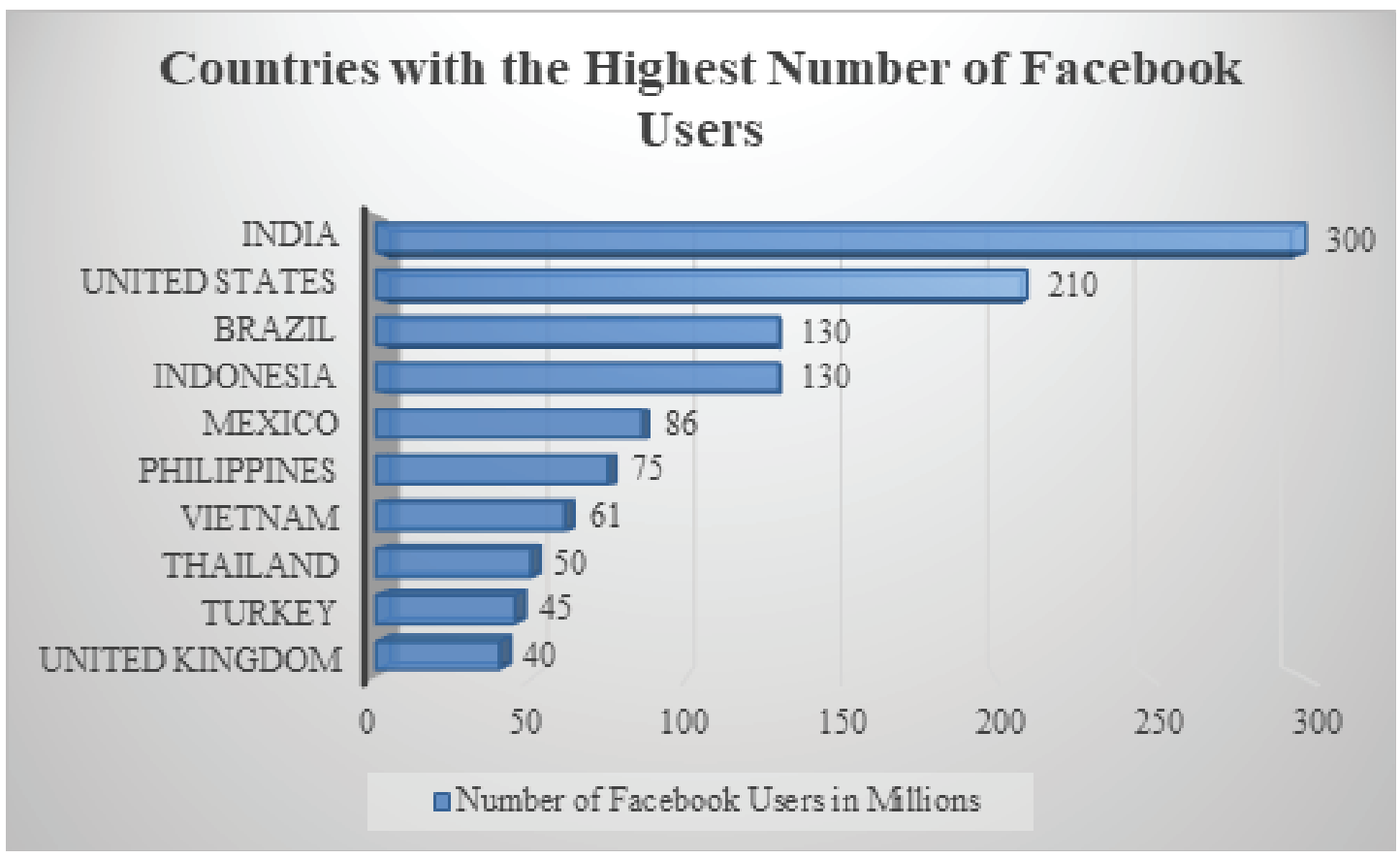

Figure 1: Leading countries based on number of Facebook users (in millions).

One of the most popular social media applications is Facebook, with 2.32 billion active users in the world. Based on the data from Statista (2019), as of January 2019, India claims the first position of countries with the highest number of Facebook users with 300 million users, followed by the United States with 210 users. Meanwhile Indonesia shares the $3^{\text {rd }}$ position with Brazil with 130 million Facebook users (look at Figure 1 for details). This ranking report indicates that Facebook has a great potential to be used in Indonesian EFL teaching and learning context. In addition, Facebook's popularity worldwide could also be considered as its potential to be integrated in EFL teaching and learning as it provides its users with opportunity to interact with people of different mother tongues and countries of origin. Thus, in this situation Facebook users could practice their English as the world's most widely spoken language used (Fithriani, 2018b).

In sync with this indication, some ELF teachers in Indonesia has started using Facebook in their classes. Studies also show positive impacts of this application as a potential tool for EFL teaching and learning. A research by Khusnita (2017) indicates that students' score improved in the post-test after Facebook is used as the media to write recount text. In line with this, a research by Nurhidayati (2014) also reveals that students' writing score has improved in every cycle after the use of Facebok as the media. Susanti (2013) 
investigated students' attitude toward Facebook for ELT found that most of the students agree about the use of Facebook to improve their motivation in learning English, Similar to this finding, Rodliyah (2016) also reported students' positive response toward the Facebook group as a media to improve their writing skills, particularly in vocabulary and language structure.

\section{Research Method}

This study applied a case study approach, which is qualitative in nature. The participants of this study were 53 students ( 40 female and 13 male students) taking an Advanced Writing class in a state university in Medan. The data were collected using three instruments; (1) questionnaire consisting of close-ended and open-ended parts; (2) semi-structured open-ended in-depth interview; and (3) observation. The questionnaire and interview were applied to collect the data concerning students' engagement and experiences in using social media, particularly Facebook to support their English language learning. Meanwhile, the observation was conducted to obtain the data related to students' participation on Facebook discussion and activities. The data collected in this study were analyzed using two methods; frequency count for quantitative data regarding students' engagement on Facebook and thematic content analysis for qualitative data regarding students' perceptions of its effectiveness.

\section{Result and Discussion}

The objective of this study was to investigate students' perceptions of the effectiveness of Facebook as a learning tool in an EFL writing classroom. The data collected in this study could be categorized into two: first, students' engagement and experience in using social media to support their learning in English writing class and second, students' perspectives of the effectiveness of Facebook to support their learning in writing class. The followings are the results of data analysis concerning the two categories.

\subsection{Students' engagement on social media}

The close-ended part of the questionnaire is employed to obtain students' demographic data related to the use of social media applications, with more emphasis on their experiences in using Facebook. The results of data analysis reveal that all students are active users of different social media platforms which include Facebook, Instagram, 
Twitter, and others such as Blogger, Snapchat, and YouTube. Among those social media apps mentioned, Facebook is named as the most used social media application (app) by the participants of this study with a total number of 52 users as seen in Figure 2. In terms of students' engagement on Facebook, the data as presented in Figure 3 show that most participants (77\%) are active users who frequently login to the app either every day $(n=17)$ or four to five times a week $(n=23)$. Only $2 \%(n=1)$ of the participants reported to login to Facebook less than once a week.

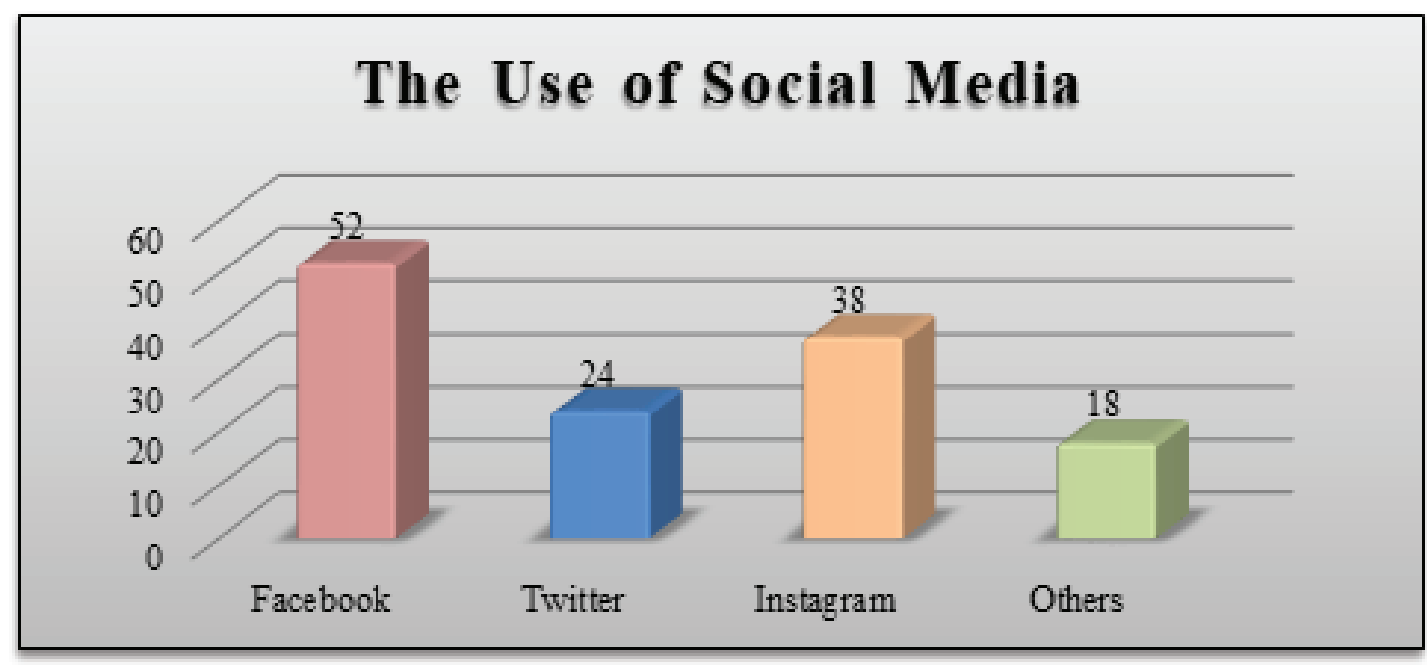

Figure 2: Students' experiences with social media.

These findings related to students' prior experiences and engagement on Facebook emphasize the indication about the great potential of this application to be integrated into educational practices in Indonesia. Since most students are already active Facebook users, it means that the teachers do not need to give them introductory trainings on how to use the application. Furthermore, this also means the facilities supporting the use of Facebook such as handheld devices and internet connection will not be an issue that needs solution from educational institutions.

\subsection{The effectiveness of facebook as a learning tool}

The responses to the open-ended part of the questionnaire provided initial information related to students' experiences of writing class activities on Facebook platform. The information was then used in designing the interview containing questions to obtain deeper information in addition to what they have stated in the questionnaire. The data from both instruments were then analyzed to allow themes related to students' perspectives of the effectiveness of Facebook as a learning tool in EFL writing class emerge. The results are the followings: 


\section{Frequency of Facebook Activity}

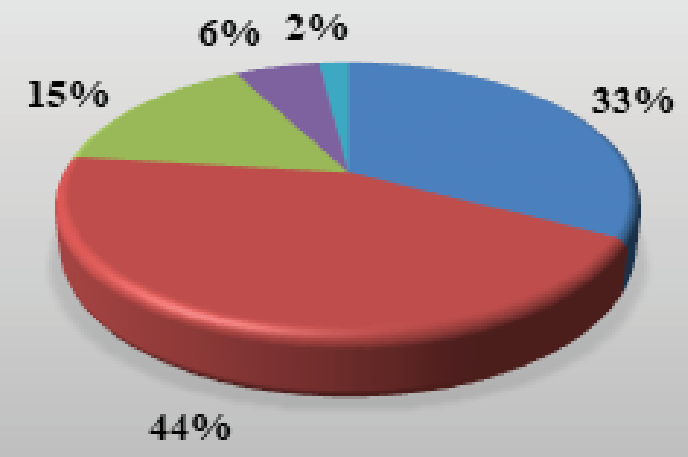

Figure 3: The frequency of students' activities on Facebook.

\subsubsection{Theme 1: Boosting confidence}

The first theme emerged from the data reveals that the use of Facebook as a learning tool in EFL writing class helps the students boost their confidence in using English as means of communication. Most students report that after taking part in Facebook class discussion in the first few meetings, they admit reading and writing more in English when communicating through the application. The students' self-claim indicating that the use of Facebook in writing class help boost their confidence in using the language to interact on the social media platform is synchronized with what the students report in their questionnaire. As can be seen in Figure 4, although they use English more for reading activities compared to writing ones both prior and after the study, it can be seen there are improvements in terms of the use of the language in both types of activities. Thus, this result may indicate that the students gain more self confidence in using the language after practicing it through Facebook class activities.

\subsubsection{Theme 2: Encouraging participation}

That Facebook encourages participation in class activities becomes the second theme emerged related to the effectiveness of Facebook as perceived by the students. Most students state that they are actively involved in almost all learning activities in the Facebook writing group. Their statement is in line with what they report in the questionnaire. As can be observed in Figure 5, all students take part in commenting their peers' post or replying to their peers' comments 2 to 3 times a week $(n=29)$ or even 4 to 6 times a week $(n=15)$. They also diligently read their peers' opinions shared through their posts 


\section{English Language Use on Facebook}

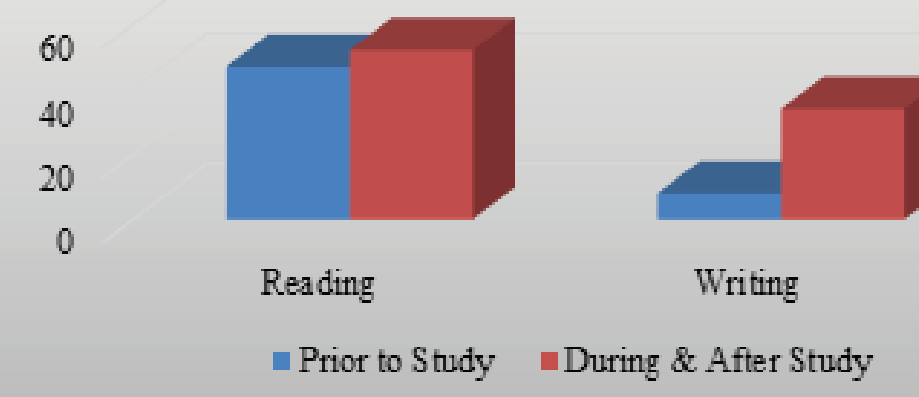

Figure 4: Students' Language Use on Facebook.

or comments. However, in terms of sharing their own opinion by starting a post is not done frequently as most students $(n=41)$ do it less than once a week.

\subsubsection{Theme 3: Improving fluency}

The final theme related to the benefits of Facebook use in EFL writing class as perceived by the students is the improvement of writing fluency. The majority of the students admit that it is much easier for them to express themselves through written communication on Facebook after they experience various learning activities on the Facebook writing group. Prior to this study, most of them say that it might take them more than half an hour to write a post in English on their Facebook timeline due to the lack of ideas of the topic to write. However, after experiencing this Facebook-enhanced writing class, they agree that they could write much faster even when they do not plan any topic to discuss yet.

\section{Conclusion}

In this era of Industry 4.0, social media has become the part of part of today's society. This means that the use of social media should also be maximized in every aspect of human's life including in EFL language teaching and learning. This study finds that social media applications have great potential to be integrated in EFL language skill classes in Indonesian context. Furthermore, this study also shows that the digital native students in this study find Facebook effective in enhancing their EFL learning process, particularly their writing skills at least in three aspects; boost their confidence in using 


\section{Frequency of Class Activities on Facebook}

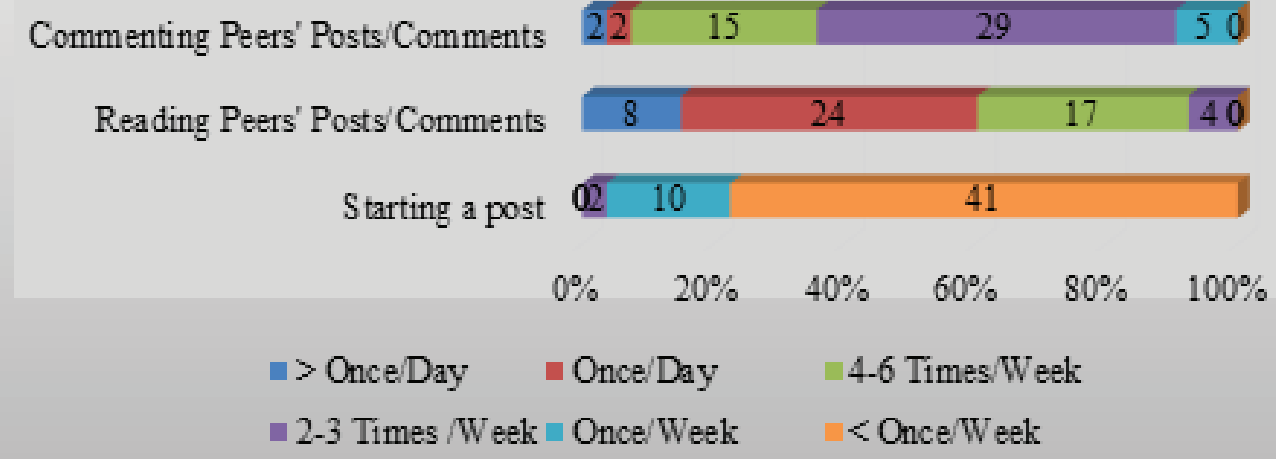

Figure 5: Frequency of Students' Facebook Activities.

the language, encourage their participation in class activities, and help improve their fluency in English writing.

Based on the findings of this study, it is recommended that social media applications, particularly Facebook be used and integrated in EFL classes in Indonesia. However, it is important to remember teachers' supervision and guidance is still much needed to ensure the use of social media in EFL classes in accordance with the purpose of the teaching and learning previously set.

\section{References}

[1] Ahmad, I. (2019, January 1) The most popular social media platforms of 2019. Digital Information World. Retrieved from https://www.digitalinformationworld.com/2019/01/ most-popular-global-social-networks-apps-infographic.html

[2] Ahmadi, M. R. (2018). The Use of Technology in English Language Learning: A literature review. Journal of Research in English Education, 3(2).

[3] Alsaleem, B.I.A. (2014). The effect of WhatsApp electronic dialogue journaling on improving writing vocabulary word choice and voice of EFL undergraduate Saudi students. Arab World English Journal, 4(3), 213-225.

[4] Arifah, A. (2014). The Use of Technology in ELT Classroom: Teachers' perspective. BRAC University, Dhaka, Bangladesh.

[5] Bransford, J., Brown, A., \& Cocking, R. (2000). How people learn: Brain, mind, experience, and school. Washington DC: National Academic Press. 
[6] Chapelle, C. A., \& Jamieson, J. (2008). Tips for teaching with CALL: Practical approaches to CALL. White Plains, NY: Pearson Education Inc

[7] Darmawati. (2018). Improving Speaking Skill through Mobile-Assisted Language Learning (MALL). Jurnal Teknologi Sistem Informasi Dan Aplikasi, 1(1).

[8] Fithriani, R. (2017). Indonesian students' perceptions of written feedback in second language writing (Doctoral Dissertation). Retrieved from https://digitalrepository. unm.edu/educ_llss_etds/87/

[9] Fithriani, R. (2018a). Cultural influences on students' perceptions of written feedback in L2 writing. Journal of Foreign Language Teaching \& Learning, 3(1), 1-13.

[10] Fithriani, R. (2018b). Discrimination behind NEST and NNEST Dichotomy in ELT Professionalism. in The 1st Annual International Conference on Language and Literature, KnE Social Sciences, (pp. 741-755). DOI 10.18502/kss.v3i4.1982

[11] Fithriani, R., Rafida, T. \& Siahaan, A. (2019). Integrating online blogging into EFL writing instruction: Exploring students' perceptions. Paper presented the $7^{\text {th }}$ UNNES International Conference on English Language Teaching, Literature and Translation (ELTLT) 2018, Semarang, Indonesia.

[12] Gilakjani, A. (2017). A Review of the Literature on the Integration of Technology into the Learning and Teaching of English Language Skills. International Journal of English Linguistics, 7(5), 95-106.

[13] Hennessy, S., Ruthven, K., \& Brindley, S. (2005). Teacher Perspectives on Integrating ICT into Subject Teaching: Commitment, Constraints, Caution, and Change. Journal of Curriculum Studies, 37(2), 155-192. https://doi.org/http://dx/doi.org/10. 1080/0022027032000276961.

[14] Husain, O. (2018, March 13). An overview of Indonesia's internet market and what's to come. Ecommerce IQ. Retrieved from https://ecommerceiq.asia/indonesia-internetmarket-overview/

[15] Keser, H., Uzunboylu, H., \& Ozdamli, F. (2012). The trends in technology supported collaborative learning studies in 21 st century. World Journal on Educational Technology, 3(2), 103-119.

[16] Khusnita, D. (2017). The Use of Facebook to Improve Students' Skill and Increase. In English Language and Literature International Conference (ELLiC) Proceedings. Semarang: Universitas Negeri Semarang.

[17] Larsen-Freeman, D., \& Anderson, M. (2011). Techniques and Principles in Language Learning. Oxford: OUP.

[18] Miangah, T. M. \& Nezarat, A. (2012). Mobile-assisted language learning. International Journal of Distributed and Parallel Systems, (3)1, 309-319. 
[19] Nurhidayati, D. (2014). The Use of Facebook to Improve Writing Skill of the Eighth Grade Students of MTs Miftahul Huda Pati in the Academic Year 2013/2014. Maria Kudus University.

[20] Parvin, R. H., \& Salam, S. F. (2015). The effectiveness of using technology in English language classrooms in government primary schools in Bangladesh. FIRE: Forum for International Research in Education, 2(1), 47-59. Retrieved from http://preserve. lehigh.edu/fire/vol2/iss1/5

[21] Prensky, M. (2001). Digital Natives, Digital Immigrants. On the Horizon, 9(5), 1-6.

[22] Rionaldi, R. (2016). Mobile-assisted language learning in higher learning institutions: Practices and attitudes toward using smart phone applications. in Proceedings of International Conference on Technology, Innovation, and Society (ICTIS) 2016, (pp. 291-296). Retrieved from https://eproceeding.itp.ac.id/index.php/ictis2016/ictis2016/ paper/viewPDFInterstitial/72/52

[23] Rodliyah, R. S. (2016). Using a Facebook Closed Group to Improve EFL Students' Writing. TEFLIN, 27(1), 82-100. https://doi.org/http://dx.doi.org/10.15639/teflinjournal. $\mathrm{V} 27 \mathrm{i} 1 / 82-100$

[24] Segav, E. (2014). Mobile learning: improve your English anytime, anywhere. Retrieved March 21, 2019, from https://www.britishcouncil.org/voices-magazine/ mobile-learning-improve-english-anytime-anywhere

[25] Statista. (2019). Leading countries based on number of Facebook users as of January 2019 (in millions). Retrieved March 21, 2019, from www.statista.com/statistics/268136/ top-15-countries-based-on-number-of-facebook-users/

[26] Susanti, A. (2013). Indonesian EFL Students' Attitude Toward Facebook for English Learning. In SELT 2013 Proceeding. Ahmad Dahlan University.

[27] Ulfa, S. (2013, October). Implementing mobile assisted language learning in rural schools for enhancing learning opportunity. Paper presented at the Asian Conference on Education, Osaka, Japan. Retrieved from http://iafor.info/archives/ offprints/ace2013-offprints/ACE2013_0356.pdf

[28] Yudhiantara, R. A. \& Nasir, I. A. (2017). Toward mobile-assisted language learning (MALL): Reaping mobile phone benefits in classroom activities. Register Journal, 10(1), 12-28. 